\title{
Genome-wide transcriptional profiling of peripheral blood leukocytes from cattle infected with Mycobacterium bovis reveals suppression of host immune genes
}

Kate E Killick', John A Browne ${ }^{1}$, Stephen DE Park1, David A Magee', Irene Martin ${ }^{1}$, Kieran G Meade², Stephen V Gordon ${ }^{1,3}$, Eamonn Gormley ${ }^{4}$, Cliona O'Farrelly ${ }^{5}$, Karsten Hokamp ${ }^{6}$ and David E MacHugh ${ }^{1,3^{*}}$

\begin{abstract}
Background: Mycobacterium bovis is the causative agent of bovine tuberculosis (BTB), a pathological infection with significant economic impact. Recent studies have highlighted the role of functional genomics to better understand the molecular mechanisms governing the host immune response to M. bovis infection. Furthermore, these studies may enable the identification of novel transcriptional markers of BTB that can augment current diagnostic tests and surveillance programmes. In the present study, we have analysed the transcriptome of peripheral blood leukocytes (PBL) from eight M. bovis-infected and eight control non-infected age-matched and sex-matched Holstein-Friesian cattle using the Affymetrix ${ }^{\circledR}$ GeneChip ${ }^{\circledR}$ Bovine Genome Array with 24,072 gene probe sets representing more than 23,000 gene transcripts.
\end{abstract}

Results: Control and infected animals had similar mean white blood cell counts. However, the mean number of lymphocytes was significantly increased in the infected group relative to the control group $(P=0.001)$, while the mean number of monocytes was significantly decreased in the BTB group $(P=0.002)$. Hierarchical clustering analysis using gene expression data from all 5,388 detectable mRNA transcripts unambiguously partitioned the animals according to their disease status. In total, 2,960 gene transcripts were differentially expressed (DE) between the infected and control animal groups (adjusted $P$-value threshold $\leq 0.05$ ); with the number of gene transcripts showing decreased relative expression $(1,563)$ exceeding those displaying increased relative expression $(1,397)$. Systems analysis using the Ingenuity ${ }^{\circledR}$ Systems Pathway Analysis (IPA) Knowledge Base revealed an overrepresentation of DE genes involved in the immune response functional category. More specifically, $64.5 \%$ of genes in the affects immune response subcategory displayed decreased relative expression levels in the infected animals compared to the control group.

Conclusions: This study demonstrates that genome-wide transcriptional profiling of PBL can distinguish active $M$. bovis-infected animals from control non-infected animals. Furthermore, the results obtained support previous investigations demonstrating that mycobacterial infection is associated with host transcriptional suppression. These data support the use of transcriptomic technologies to enable the identification of robust, reliable transcriptional markers of active M. bovis infection.

\footnotetext{
* Correspondence: david.machugh@ucd.ie

'UCD College of Agriculture, Food Science and Veterinary Medicine,

University College Dublin, Belfield, Dublin 4, Ireland

Full list of author information is available at the end of the article
}

(C) 2011 Killick et al; licensee BioMed Central Ltd. This is an Open Access article distributed under the terms of the Creative Commons 


\section{Background}

Bovine tuberculosis (BTB) poses a serious threat to the health of domestic cattle herds worldwide. Infection is caused by the bacterium Mycobacterium bovis, an intracellular pathogen closely related to Mycobacterium tuberculosis-the causative agent of human tuberculosis. $M$. bovis infection is often slow and progressive with limited clinical symptoms. Although improved diagnostic tests and slaughter policies have done much to control and reduce the incidence of infection, BTB has remained recalcitrant to eradication in many countries where control programmes have been implemented [1-3].

Failure to detect and remove all infected animals from herds is partly due to limitations in the sensitivity of the current diagnostic tests, which often comprise an in vivo single intradermal comparative tuberculin test (SICTT) performed alone, or in combination with an in vitro enzyme-linked immunosorbent assay (ELISA)-based test for interferon gamma (IFN- $\gamma$ )-an established biomarker of mycobacterial infection [4-6]. Diagnoses can be further confounded by exposure to environmental nonpathogenic mycobacterial antigens, which can generate false SICTT-positive signals in cattle [7]. Protection from natural $M$. bovis infection in cattle may be achieved through vaccination with $M$. bovis bacillus Calmette-Guérin (BCG); however, the level of protection attained is variable. In addition, current diagnostics cannot effectively differentiate between $M$. bovis-infected and BCG-vaccinated animals, thus compromising management strategies [8]. Consequently, there is a pressing need for novel $M$. bovis diagnostic methods with increased sensitivity and specificity.

The host immune response to mycobacterial infection is a complex process that involves interaction between the innate and adaptive immune systems. Upon initial exposure (generally via inhalation), bacilli are phagocytosed by host alveolar macrophages, which recognise mycobacteria using a diverse range of pathogen recognition receptors (PRRs), such as the Toll-like receptors (TLRs) and the nucleotide-binding oligomerisation domain (NOD)-like receptors (NLRs) [9-13]. Activation of macrophage PRR-mediated signalling pathways result in the release of endogenous cytokines, which initiate an adaptive immune response characterised by the secretion of proinflammatory cytokines, such as IFN- $\gamma$ and tumour necrosis factor (TNF- $\alpha$ ), by activated T cells [14]. In particular, IFN- $\gamma$ activates infected macrophages and enables the formation of granulomas-collections of inflammatory cells comprising $\mathrm{T}$ cells, B cells, noninfected macrophages and neutrophils, which surround infected macrophages and act as barriers to contain and prevent dissemination of the infection [15]. In most cases, the host innate and adaptive immune systems successfully control mycobacterial growth within granulomas resulting in asymptomatic latent infection $[16,17]$. However, in some cases impairment of immune function can result in the development of active tuberculosis leading to disease progression [3,17-20].

Recently, functional genomic technologies have been used to investigate the molecular mechanisms and cellular pathways underlying the host immune response to mycobacterial infection [[21,22], for reviews see [23,24]]. Furthermore, results from these studies have the potential to identify molecules that are critical for host/pathogen survival during infection, and which may serve as robust, reliable transcriptional markers of mycobacterial infection [22].

Previously, we investigated the transcriptional profiles of peripheral blood mononuclear cells (PBMC) from $M$. bovis-infected and non-infected control animals using the immuno-specific BOTL-5 microarray (containing 1,391 gene probe sets; Gene Expression Omnibus [GEO] accession: GPL5751) and showed that suppression of innate immune genes was associated with BTB [25]. In the current study, we extend this earlier work by investigating the transcriptional profile of peripheral blood leukocytes (PBL) isolated from eight $M$. bovis-infected and eight non-infected control animals using the genomewide high-density Affymetrix ${ }^{\circledR}$ GeneChip ${ }^{\circledR}$ Bovine Genome Array. These 16 animals were sampled specifically for the present study and have not been used for any previous research work. The Affymetrix ${ }^{\circledR}$ GeneChip ${ }^{\circledR}$ Bovine Genome Array contains 24,072 gene probe sets representing more than 23,000 gene transcripts http:// www.affymetrix.com. In addition, we have adopted a systems biology approach using the Ingenuity ${ }^{\mathbb{B}}$ Systems Pathway Analysis (IPA) Knowledge Base http://www. ingenuity.com for analysis of both over-represented cellular functions and known molecular canonical pathways from the resulting gene expression data.

The results presented in the current study contribute a novel layer of information regarding the gene expression profile of PBL from $M$. bovis-infected animals and highlight the value of high-throughput genomic technologies in understanding the host immune response to BTB. Furthermore, these results may facilitate the development of novel diagnostics for the detection of $M$. bovis infection in domestic herds.

\section{Methods}

\section{Experimental animals}

Sixteen age-matched female Holstein-Friesian animals from cattle herds that had not been analysed previously were used for this study. Eight infected individuals were selected from a panel of naturally M. bovis-infected animals maintained for on-going disease surveillance at the Irish Department of Agriculture, Fisheries and Food, 
Backweston Laboratory Campus (Celbridge, Co. Kildare, Ireland). These animals had a positive single intradermal comparative tuberculin test (SICTT) result where the skin-fold thickness response to purified protein derivative (PPD)-bovine exceeded that of PPD-avian by at least $12 \mathrm{~mm}$. All of these animals were also positive for the whole blood IFN- $\gamma$-based BoviGAM ${ }^{\circledR}$ assay [Prionics AG, Switzerland] (data not shown). In addition, these cattle were confirmed for BTB following detailed postmortem pathological examination and/or culture. Briefly, bronchial, mediastinal, submandibular, retropharyngeal, mesenteric and hepatic lymph nodes and lungs were examined macroscopically for tuberculosis lesions. Suspected lesions were cultured on Stonebrinks and Lowenstein-Jensen media at $37^{\circ} \mathrm{C}$ for eight weeks to detect $M$. bovis [26]. Non-infected control animals were selected from a herd with no recent history of $M$. bovis infection. The control animals were shown to be negative for both the SICTT and IFN- $\gamma$ tests (data not shown). All animal procedures detailed in this study were carried out according to the provisions of the Cruelty to Animals Act (licenses issued by the Department of Health and Children) and ethics approval for the study was obtained from the UCD Animal Ethics Committee.

\section{Blood collection}

Two $8 \mathrm{ml}$ vacutainers ${ }^{\circledR}$ (Becton-Dickinson Ltd., Dublin, Ireland) of heparinised blood were collected from each animal, approximately 12 months after positive SICTT testing. One vacutainer ${ }^{\circledR}$ was retained for haematological analysis using a Cell-Dyn 3500 haematology analyser (Abbott Laboratories Ireland Ltd., Dublin, Ireland); all haematological analysis was performed using $1 \mathrm{ml}$ of blood. The other vacutainer ${ }^{\circledR}$ was used for RNA isolation from peripheral blood leukocytes (PBL); the whole white blood cell fraction consisting of $\mathrm{T}$ and $\mathrm{B}$ lymphocytes, NK cells, monocytes, neutrophils, basophils and eosinophils. The count data from the leukocyte cell populations of infected and non-infected animals were assessed using the two-sample, two-tailed Student's $t$ test, following Kolmogorov-Smirnov tests of normality and Levene's F-test for equality of variance using the Minitab statistical package version 16 (Minitab Ltd., Coventry, UK).

\section{RNA extraction and microarray analysis}

All RNA extractions were performed within two hours of blood collection. Briefly, $7.5 \mathrm{ml}$ of whole heparinised blood was mixed with $42.5 \mathrm{ml}$ of erythrocyte blood lysis buffer $\left(10 \mathrm{mM} \mathrm{KHCO} 3,150 \mathrm{mM} \mathrm{NH}_{4} \mathrm{Cl}, 1 \mathrm{mM}\right.$ EDTA $\mathrm{pH} 8.0$ ), and incubated for $5 \mathrm{~min}$ at room temperature with gentle agitation. Following centrifugation (750 g for $10 \mathrm{~min}$ ) the pelleted cells were washed once with $1 \times$ phosphate buffered saline (Invitrogen Ltd., Paisley, UK). The cell pellet was then fully resuspended in $2 \mathrm{ml}$ Trizol $^{\circledR}$ reagent (Invitrogen Ltd., Paisley, UK) and RNA was extracted as per the manufacturer's instructions. The RNA was further purified using an RNeasy $\left.{ }^{(}\right)$kit with on-column DNase treatment (Qiagen Ltd., Crawley, UK) according to the manufacturer's instructions. RNA quantity and quality was assessed using both the NanoDrop $^{\mathrm{TM}} 1000$ spectrophotometer (Thermo Fisher Scientific, Waltham, MA, USA) and the Agilent 2100 Bioanalyzer using an RNA 6000 Nano LabChip kit (Agilent Technologies, Cork, Ireland). All samples displayed a 260/280 ratio greater than 1.8 and RNA integrity numbers (RIN) greater than 8.0.

cDNA labelling, hybridisation and scanning for the microarray experiments were performed by Almac Diagnostics (Craigavon, Co. Armagh, Northern Ireland) using a one-cycle amplification/labelling protocol on the Affymetrix $^{\circledR}$ GeneChip ${ }^{\circledR}$ Bovine Genome Array (Affymetrix UK Ltd., High Wycombe, UK).

\section{Statistical analysis of microarray data}

Affymetrix $^{\circledR}$ GeneChip ${ }^{\circledR}$ Bovine Genome Array data were analysed using Bioconductor [[27]; http://www. bioconductor.org] contained within the $\mathrm{R}$ statistical package http://www.r-project.org. Normalisation of raw data was performed using the Factor Analysis for Robust Microarray Summarization (FARMS) algorithm. The FARMS algorithm uses only perfect match (PM) probes and a quantile normalization procedure, providing both $P$-values and signal intensities [28]. In addition, gene expression profiles for each animal were clustered using the Hierarchical Ordered Partitioning and Collapsing Hybrid ( $\mathrm{HOPACH}$ ) clustering algorithm in Bioconductor with Euclidean distance as the distance metric [29].

Normalised data were then further subjected to filtering for informative probes sets using the $\mathrm{R}$ package I/ NI-calls [30]. This defines a probe set as being informative when many of its probes reflect the same change in mRNA concentration across arrays. Differentially expressed genes were extracted using the Linear Models for Microarray Data (LIMMA) package http://bioconductor.org/packages/release/bioc/html/limma.html contained within the $\mathrm{R}$ statistical package. Genes displaying differential expression patterns between control and infected groups were annotated using the Affymetrix ${ }^{\circledR}$ bovine gene annotation http://www.affymetrix.com. The Benjamini-Hochberg multiple-testing correction method [31] was applied to all differentially expressed genes to minimise the false discovery rate (FDR) and adjusted $P$ values for differentially expressed (DE) genes were calculated. For genes represented by multiple probe sets the mean expression value is reported. Bootstrapping for 
the hierarchical clustering analysis was performed using a custom Perl script (see Additional file 1).

\section{Systems biology analyses}

Ingenuity ${ }^{\circledR}$ Systems Pathway Analysis (IPA, Ingenuity Systems, Redwood City, CA, USA; http://www.ingenuity. com) was used to identify canonical pathways and functional processes of biological importance within the list of DE genes. The Ingenuity ${ }^{\circledR}$ Knowledge Base contains the largest database of manually-curated and experimentally-validated physical, transcriptional and enzymatic molecular interactions. Furthermore, each interaction in the Ingenuity ${ }^{\circledR}$ Knowledge Base is supported by previously published information.

For the IPA analyses, the Affymetrix ${ }^{\circledR}$ GeneChip ${ }^{\circledR}$ Bovine Genome Array was used as a reference gene set. All DE genes with an adjusted $P$ value $\leq 0.05$ were included. For duplicate probe IDs, the average $\log _{2}$ expression fold change was used. Only DE genes mapping to molecules in the Ingenuity ${ }^{\circledR}$ Knowledge Base were used for systems analysis. Functional analysis of genes was performed using IPA to characterise the biological functions of the DE genes between the BTB and control groups. For this, IPA performed an over-representation analysis that categorises the DE genes within the uploaded list into functional groups using the Ingenuity ${ }^{\circledR}$ Knowledge Base. Each category in IPA is ranked based on the number of DE genes falling into each functional group. Right-tailed Fisher's exact tests were used to calculate a $P$-value for each of the biological function assigned to list of DE genes.

IPA contains a large library of known canonical pathways that were overlaid with the DE genes to identify major biological pathways associated with $M$. bovis infection in PBL. The significance of the association between DE genes and the canonical pathway was assessed using two methods: (1) a ratio of the number of molecules from the DE gene data set that map to the pathway, compared to the total number of molecules that map to the canonical pathway based on the reference gene list; and (2) a Fisher's exact test that generates a $P$-value for the assignment of the DE genes to a particular canonical pathway compared to the reference gene list. Canonical pathways were then overlaid with the expression values of the DE genes.

\section{Real time quantitative reverse transcription PCR (qRT- PCR) validation of microarray results}

cDNA was prepared using $500 \mathrm{ng}$ of total RNA from each sample from the microarray study using the High Capacity cDNA Reverse Transcription Kit (Applied Biosystems, Warrington, UK) in a $20 \mu$ reaction using random primers according to the manufacturer's instructions. cDNA was diluted 1:50 and stored at $-20^{\circ} \mathrm{C}$ prior to performing real time quantitative reverse transcription PCR (qRT-PCR).

Real time qRT-PCR reactions were performed using Fast SYBR ${ }^{\circledR}$ Green Master mix (Applied Biosystems, Warrington, UK) on a 7500 Fast Real-Time PCR System apparatus (Applied Biosystems, Warrington, UK). Each reaction $(20 \mu \mathrm{l})$ contained $5 \mu \mathrm{l}$ of the diluted cDNA (equivalent to $2.5 \mathrm{ng}$ of total RNA) and $300 \mathrm{nM}$ final concentration each of forward and reverse primer. Additional file 2, Table S1 provides a complete list of primer sequences and the target accession numbers for each real time qRT-PCR amplicon analysed. Real time qRTPCR primers were designed using the Primer3 software $[32,33]$ and where possible intron-spanning primers were selected (see Additional file 2, Table S1). Negative real time qRT-PCR controls and a six-point, four-fold dilution series from pooled cDNA from all animals were included on every real time qRT-PCR plate and individual PCR efficiencies were determined from the standard curves using the qbase ${ }^{\text {PLUS }}$ software package [[34]; Biogazelle NV, Zwijnaarde, Belgium].

The PCR thermal cycling program consisted of one cycle at $50^{\circ} \mathrm{C}$ for $2 \mathrm{~min}$, one cycle at $95^{\circ} \mathrm{C}$ for $10 \mathrm{~min}$, followed by 40 cycles at $95^{\circ} \mathrm{C}$ for $15 \mathrm{~s}$ and $60^{\circ} \mathrm{C}$ for 1 min. A dissociation step was included to confirm amplification specificity and real time qRT-PCR products were analysed on a $2 \%$ agarose gel to confirm the presence of a single discrete amplicon of the correct size. All real time qRT-PCR data was analysed using the qba$\mathrm{se}^{\text {PLUS }}$ software package with efficiency correction and normalization was performed using two reference genes: the 60 S ribosomal protein L19 gene (RPL19) and peptidylprolyl isomerase A (cyclophilin A) gene (PPIA). The two reference genes were selected using the geNorm algorithm in the qbase ${ }^{\text {PLUS }}$ package from a panel of eight genes tested (geNorm $\mathrm{M}>0.15$ ).

The qbase ${ }^{\text {PLUS }}$ package generated a calibrated normalized relative quantity (CNRQ) of gene expression for each of the analysed samples. $\log _{2}$ CNRQ values for both the control and the $M$. bovis-infected animals were used for statistical analysis for all genes. One sample Kolmogorov-Smirnov tests, performed using the SPSS ${ }^{\circledR}$ version 18 software package (SPSS ${ }^{\circledR}$ Inc., Chicago, IL, USA) were applied to the residuals of the $\log _{2}$ CNRQ values for each sample prior to statistical analysis to ensure the data conformed to a normal distribution-no significant departures from normality were observed for any of the genes analysed $(P \geq 0.05)$. Two-tailed, twosample Student $t$-tests were used to assess differences between infected and control groups based on $\log _{2}$ CNQR values using SPSS and the statistical package contained within Microsoft ${ }^{\circledR}$ Excel 2010 (Microsoft Corp., Redmond, WA, USA). In addition, Levene's Ftest was applied to the infected and control group $\log _{2}$ 
CNRQ values to assess equality of variance within the two groups using SPSS prior to performing the twosample $t$-tests; equality of variance was observed for each sample group.

Geometric mean fold-changes in gene expression for the BTB group were calculated by dividing the geometric mean CNRQ value for the $M$. bovis-infected group by the geometric mean CNRQ value for the control group. The negative reciprocal in fold-change is reported where decreased gene expression was observed in the BTB group relative to the control group.

\section{Results}

Analysis of leukocyte populations in control and M. bovisinfected blood samples

The infected animals used in this study were chosen on the basis of their large responses to the comparative tuberculin skin test. The IFN- $\gamma$ levels measured in whole blood of the infected animals were at least 25-fold greater than in the healthy control cattle $(P<0.001$, data not shown), demonstrating that the infected animals were generating strong cell-mediated immune responses. At post-mortem, each of the infected animals displayed gross tuberculosis lesions in the lungs and thoracic lymph nodes and were classified as being in the advanced stage of clinical disease.

To assess potential changes in leukocyte composition between control and M. bovis-infected samples, whole blood samples were subjected to haematological analysis (Figure 1). No significant difference was observed in the total white blood cell (WBC) count between control and $M$. bovis-infected animals $(P=0.18)$. However, significant increases in the mean number of lymphocytes $(P=0.001)$ and significant decreases in the mean number of monocytes $(P=0.002)$ were observed in $M$. bovis-infected animals relative to the control animals. No significant differences in the mean number of eosinophils and neutrophils were observed between the two sample groups $(P=0.51$ and $P=0.37$, respectively).

\section{Summary of differentially expressed genes between control and $M$. bovis-infected animals identified from Affymetrix $^{\circledR}$ GeneChip ${ }^{\circledR}$ analysis}

The expression data generated for the current study are MIAME-compliant [35] and were deposited in the NCBI Gene Expression Omnibus (GEO) repository [36] with experiment series accession GSE33359. All array transcripts that passed informative probe filtering were used for cluster analysis to examine the grouping of samples based on infection status (Figure 2). In total, 5,388 transcripts passed the filtering process and were used for the cluster analysis, which showed a clear partitioning of samples based on their disease status, indicating a distinct difference in expression profile between the two sample groups. The division of the two sample groups

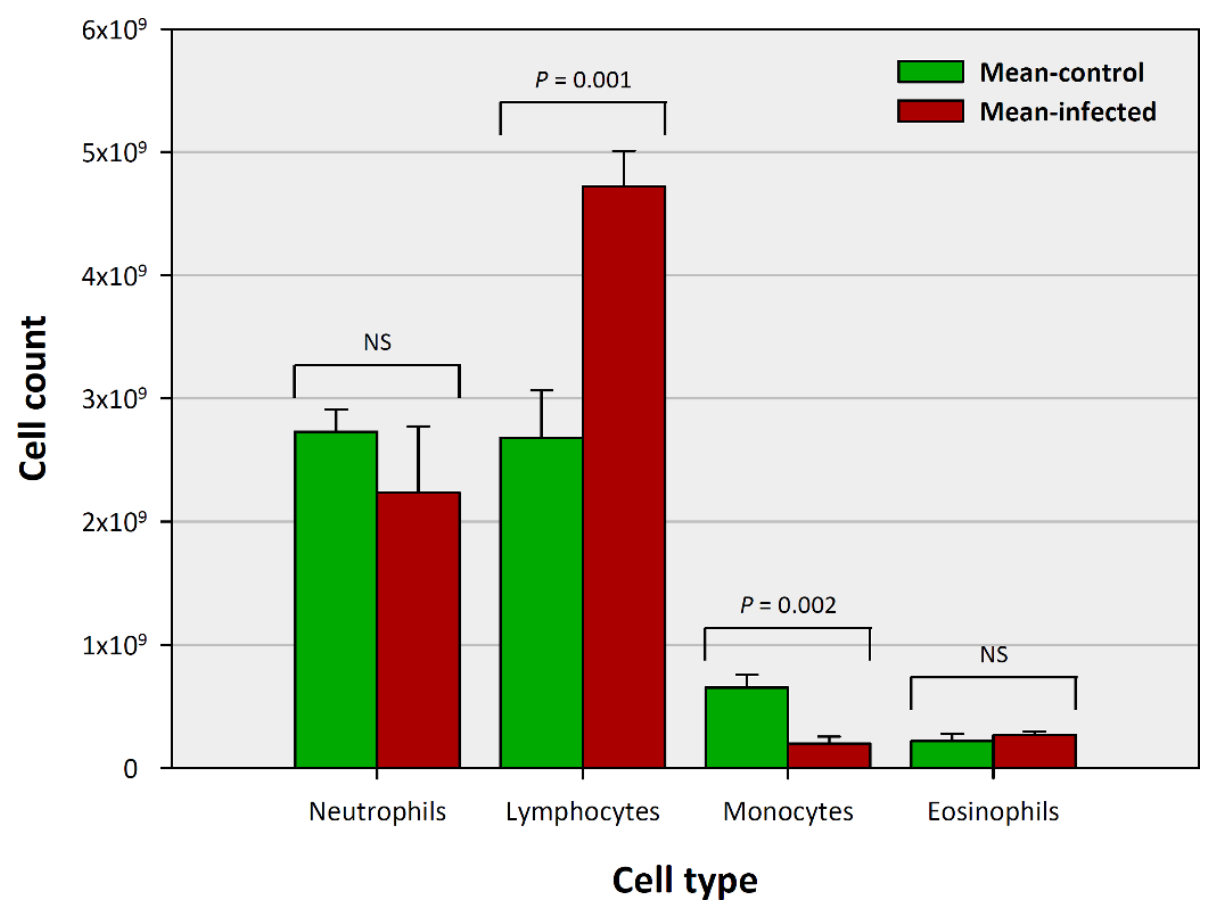

Figure 1 Mean leukocyte cell population subset counts in control and $\boldsymbol{M}$. bovis-infected animals ( $\boldsymbol{n}=\mathbf{8}$ each group). Error bars represent the standard error for each mean cell count estimate. 


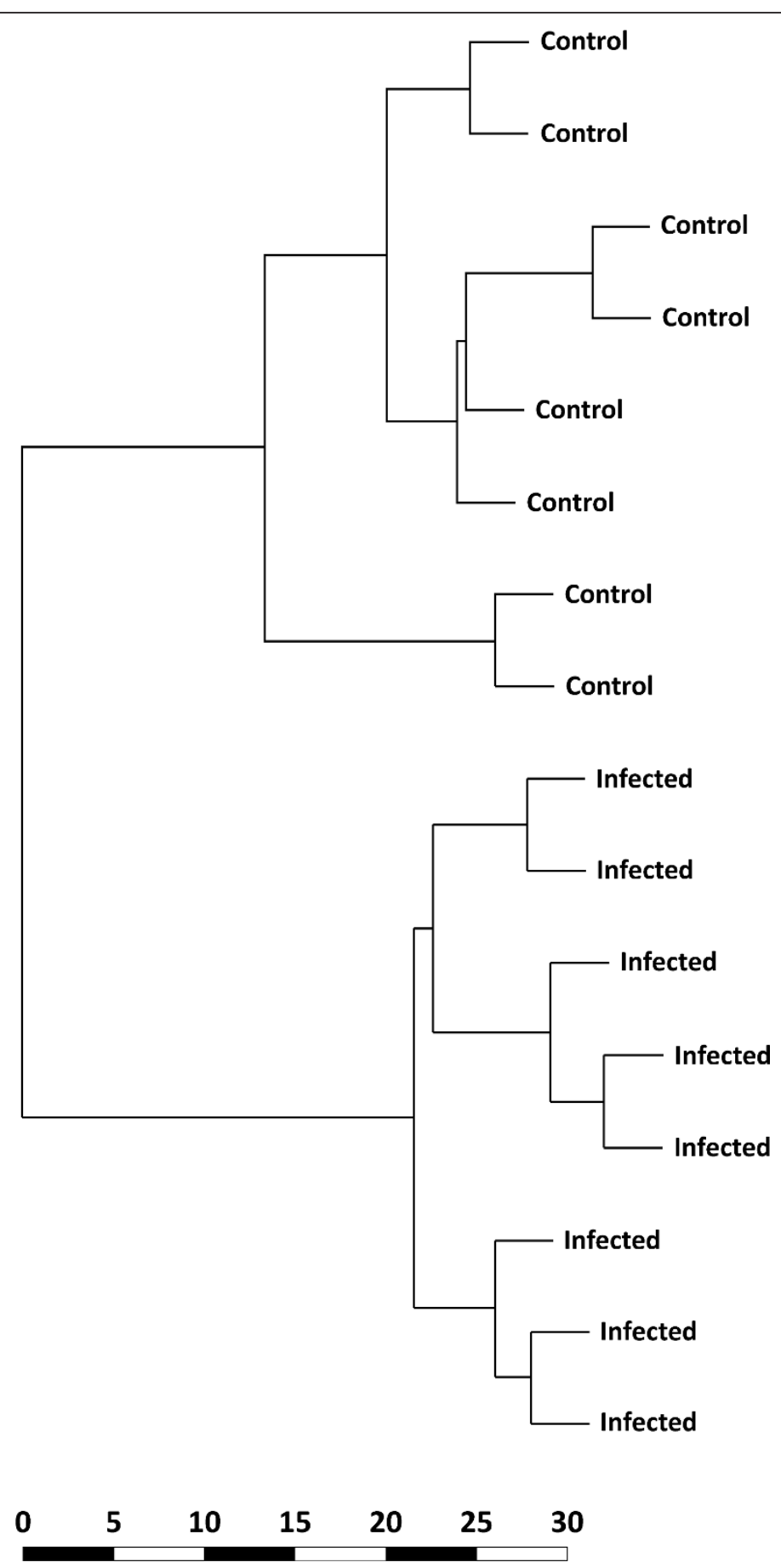

Figure 2 Hierarchical clustering dendrogram generated using the complete gene expression profiles for the $M$. bovis-infected and control animals. The dendrogram was generated from the complete gene expression dataset for each animal using the Euclidean distance metric. The division between the BTB and control animal groups was supported by a bootstrap value of 100\%.

was supported by a $100 \%$ bootstrap value after 1,000 permutations.

Genome-wide transcriptional profiles generated from the PBL of eight $M$. bovis-infected and eight control animals were compared to assess differential gene expression between the two sample groups. The microarray analysis revealed a total of 2,960 transcripts, representing 2,757 unique genes, as differentially expressed between the $M$. bovis-infected and non-infected control animals (adjusted $P$ value $\leq 0.05$ ). In summary, 1,397 
transcripts (representing 1,281 unique genes) displayed increased expression and 1,563 transcripts (representing 1,476 unique genes) displayed decreased expression in the $M$. bovis-infected group relative to the control group.

Among the DE genes with immune-related functions were genes encoding proinflammatory cytokines and other mediators of the host immune response also displayed increased relative expression in the BTB group. These included the cluster of differentiation 83 antigenencoding gene (CD83) [+4.92-fold]; the chemokine (C-C motif) ligand 2 gene (CCL2) [+2.85-fold]; the chemokine (C-X-C motif) ligand 5 gene (CXCL5) [+3.87-fold]; the cytotoxic $\mathrm{T}$-lymphocyte-associated protein 4 gene (CTLA4) [+3.20-fold]; the chemokine (C-X-C motif) receptor 4 gene $(C X C R 4)$ [+2.64-fold]; the interleukin 8 gene (IL8) [+2.15-fold] and the interleukin 1 alpha gene (IL1A) [+1.89-fold]. The genes encoding the TNF- $\alpha$ (TNF) and IFN- $\gamma$ (IFNG) cytokines, two recognised biomarkers of $M$. bovis infection, were not differentially expressed between the two groups.

Reduced relative expression of host immune-related genes was also observed in the M. bovis-infected group relative to the control group. Among these were the antimicrobial beta-defensin 10 gene (DEFB10) [-3.38fold]; the triggering receptor expressed on myeloid cells 1 gene (TREM1) [-1.70-fold]; and the TYRO protein tyrosine kinase binding protein gene (TYROBP) [-1.38fold]. Other immune genes displaying reduced relative gene expression in the BTB group included those encoding proinflammatory cytokines such as the interleukin 15 gene (IL15) [-1.49-fold]; the interleukin 16 gene (IL16) [-1.44-fold]; and the interleukin 18 gene (IL18) [-1.72-fold].

Notably, several genes involved in TLR-mediated signalling displayed reduced relative expression in the BTB group such as the Toll-like receptor 4 gene (TLR4) [+2.41-fold]; the Toll-like receptor 2 gene (TLR2) [-1.45fold]; the TLR adaptor protein myeloid differentiation primary response gene (88) [MYD88] (-1.31-fold); the interleukin-1 receptor-associated protein kinase 4 gene (IRAK4) [-1.11-fold] and the mitogen-activated protein kinase 13 and 14 genes (MAPK13 [-1.93-fold] and $M A P K 14$ [-1.15-fold]). The gene encoding the intracellular TLR3 protein (TLR3) also displayed reduced relative expression in the BTB animals (-1.55-fold).

\section{Real time quantitative reverse transcription PCR (qRT- PCR) analysis and validation of Affymetrix ${ }^{\circledR}$ GeneChip ${ }^{\circledR}$ results}

A panel of 23 immune-related genes, including members of the interferon signalling pathway, which was recently shown to be the most significantly over-represented pathway in human patients with active TB [37], were selected for real time qRT-PCR analysis. These were CASP1, CD83, CTLA4, DEFB10, IFNB, IFNAR1, IFNG, IFNGR1, IFNGR2, IL1A, IL8, IL15, JAK1, KIR3DS1, MYD88, PTPN2, STAT1, STAT2, TLR3, TLR4, TREM1, $T Y K 2$ and TYROBP. The immune-related function of each gene and the results from these analyses are detailed in Table 1.

Thirteen of the 23 genes analysed using real time qRT-PCR (CASP1, DEFB10, IFNAR1, IL15, KIR3DS1, MYD88, PTPN2, STAT1, STAT2, TLR3, TREM1, TYK2 and $T Y R O B P)$ showed significant decreased expression $(P \leq 0.05)$ and five genes (CD83, CTLA4, IFNGR1, IL1A and $I L 8)$ displayed significant increased expression $(P \leq$ $0.05)$ in the M.bovis-infected group relative to the control animals. No statistically significant differences in expression $(P>0.05)$ were observed between the two sample groups for the remaining five genes assayed (IFNB1, IFNG, IFNGR2, JAK1and TLR4).

Twenty-two of the 23 genes analysed by real time qRT-PCR were represented on the microarray; only TYK2 was not represented. Gene expression profiles for $16 / 22(73 \%)$ of the genes analysed with real time qRTPCR were concordant with the results from the microarray analysis. Two genes (IFNGR2 and TLR4) displayed significant expression differences between the two sample groups based on the microarray results, but were not significantly different based on real time qRT-PCR data analysis. Three genes (IFNAR1, IFNGR1 and $P T P N 2)$ displayed significant differences between the two groups based on real time qRT-PCR results; however, these genes were not differentially expressed according to the microarray results. Only one gene (STAT1) displayed directionally discordant gene expression profiles between the two methods. In the M. bovisinfected group, STAT1 showed significant reduced relative expression (-1.27-fold) based on real time qRT-PCR results but displayed significant increased relative expression (+1.28-fold) according to the microarray results. The observed discrepancies between the microarray and real time qRT-PCR data may reflect differences in the sensitivity of the two analytical methods used and/or differences in the mRNA transcripts targeted by the probes (microarray) and primer pairs (real time qRT-PCR) used for the two forms of gene expression analysis.

\section{Analysis of differential gene expression using Ingenuity ${ }^{\circledR}$ Systems Pathway Analysis (IPA)}

The total number of DE genes that could be mapped to molecules in the Ingenuity ${ }^{\circledR}$ Knowledge Base was 1,869 from a total of 2,960 DE transcripts. IPA was used to categorise these 1,869 DE genes based on their functional annotation and to assess if a functional gene category contained an over-representation of genes relative 
Table 1 Gene expression fold-changes between M.bovis-infected $(n=8)$ and control $(n=8)$ based on microarray and real time qRT-PCR analyses

\begin{tabular}{|c|c|c|c|c|c|}
\hline $\begin{array}{l}\text { Gene } \\
\text { symbol }\end{array}$ & Gene name & Gene description & $\begin{array}{l}\text { Mean M.bovis-infected } \\
\text { vs control group } \\
\text { expression fold-change } \\
\text { (microarray) }\end{array}$ & $\begin{array}{l}\text { Mean M.bovis-infected vs } \\
\text { control group expression } \\
\text { fold-change (real time } \\
\text { qRT-PCR) }\end{array}$ & $\begin{array}{l}\text { Real } \\
\text { time } \\
\text { qRT-PCR } \\
\text { P-value }\end{array}$ \\
\hline CASP1 & Caspase 1 gene & $\begin{array}{l}\text { A member of the cysteine-aspartic acid } \\
\text { protease. Plays a role in the cell apoptosis }\end{array}$ & -1.45 & -1.98 & 0.001 \\
\hline CD83 & $\begin{array}{l}\text { Cluster of differentiation } \\
83 \text { gene }\end{array}$ & $\begin{array}{l}\text { A cell surface protein found in antigen } \\
\text { presenting cells. Believed to play a role in } \\
\text { antigen presentation or the cellular } \\
\text { interactions that follow lymphocyte } \\
\text { activation }\end{array}$ & +4.92 & +5.88 & $<0.001$ \\
\hline CTLA4 & $\begin{array}{l}\text { Cytotoxic T-lymphocyte- } \\
\text { associated protein } 4 \\
\text { gene }\end{array}$ & $\begin{array}{l}\text { A member of the immunoglobulin } \\
\text { superfamily and encodes a protein which } \\
\text { transmits an inhibitory signal to T cells }\end{array}$ & +3.20 & +3.46 & 0.001 \\
\hline DEFB10 & Beta-defensin 10 gene & $\begin{array}{l}\text { Host defence response to bacterial infection; } \\
\text { has antimicrobial activity }\end{array}$ & -3.38 & -12.21 & 0.018 \\
\hline$|F N B|$ & $\begin{array}{l}\text { interferon, beta } 1 \text {, } \\
\text { fibroblast }\end{array}$ & Cytokine activity & Not DE & Not DE & $>0.05$ \\
\hline IFNARI & $\begin{array}{l}\text { Interferon (alpha, beta } \\
\text { and omega) receptor } 1 \\
\text { gene }\end{array}$ & $\begin{array}{l}\text { A type I membrane protein that forms one } \\
\text { of the two chains of a receptor for } \\
\text { interferons alpha and beta }\end{array}$ & Not DE & -2.20 & $<0.001$ \\
\hline IFNG & Interferon gamma gene & $\begin{array}{l}\text { A soluble cytokine with antiviral, } \\
\text { immunoregulatory and anti-tumor properties. } \\
\text { A potent activator of macrophages }\end{array}$ & Not DE & Not DE & $>0.05$ \\
\hline IFNGRI & $\begin{array}{l}\text { Interferon gamma } \\
\text { receptor } 1 \text { gene }\end{array}$ & $\begin{array}{l}\text { Forms a heterodimer with interferon gamma } \\
\text { receptor } 2 \text {. Involved in binding of interferon } \\
\text { gamma }\end{array}$ & Not DE & +2.23 & $<0.001$ \\
\hline IFNGR2 & $\begin{array}{l}\text { Interferon gamma } \\
\text { receptor } 2 \text { gene }\end{array}$ & $\begin{array}{l}\text { Forms a heterodimer with interferon gamma } \\
\text { receptor } 1 . \text { Involved in binding of interferon } \\
\text { gamma }\end{array}$ & -1.32 & Not DE & $>0.05$ \\
\hline$\| L 1 A$ & $\begin{array}{l}\text { Interleukin 1, alpha } \\
\text { gene }\end{array}$ & $\begin{array}{l}\text { A member of the interleukin } 1 \text { cytokine } \\
\text { family produced by macrophages. Involved } \\
\text { in various immune responses, inflammatory } \\
\text { processes, and haematopoiesis }\end{array}$ & +1.89 & +2.47 & 0.009 \\
\hline 118 & Interleukin 8 gene & $\begin{array}{l}\text { A chemokine that mediates the } \\
\text { inflammatory response }\end{array}$ & +2.15 & +4.01 & $<0.002$ \\
\hline $1 L 15$ & Interleukin 15 gene & $\begin{array}{l}\text { A cytokine that regulates } T \text { and natural killer } \\
\text { cell activation and proliferation }\end{array}$ & -1.49 & -2.03 & $<0.001$ \\
\hline$J A K 1$ & Janus kinase 1 gene & $\begin{array}{l}\text { A widely expressed membrane-associated } \\
\text { phosphoprotein involved in the interferon- } \\
\text { alpha/beta and -gamma signal transduction } \\
\text { pathways }\end{array}$ & Not DE & Not DE & $>0.05$ \\
\hline KIR3DS1 & $\begin{array}{l}\text { Killer cell } \\
\text { immunoglobulin-like } \\
\text { receptor, three domains, } \\
\text { short cytoplasmic tail, } 1\end{array}$ & $\begin{array}{l}\text { A transmembrane glycoprotein expressed by } \\
\text { natural killer cells and some T cells. Involved } \\
\text { in regulation of the immune response }\end{array}$ & -1.44 & -2.63 & 0.005 \\
\hline MYD88 & $\begin{array}{l}\text { myeloid differentiation } \\
\text { primary response gene } \\
(88)\end{array}$ & $\begin{array}{l}\text { A cytosolic adapter protein that functions as } \\
\text { a signal transducer in the interleukin-1 and } \\
\text { Toll-like receptor signalling pathways }\end{array}$ & -1.31 & -2.55 & $<0.001$ \\
\hline PTPN2 & $\begin{array}{l}\text { protein tyrosine } \\
\text { phosphatase, non- } \\
\text { receptor type } 2 \text { gene }\end{array}$ & $\begin{array}{l}\text { A member of the protein tyrosine } \\
\text { phosphatase (PTP) family that is involved in } \\
\text { a variety of cellular processes including cell } \\
\text { growth, and differentiation }\end{array}$ & Not DE & -1.43 & $<0.001$ \\
\hline STAT1 & $\begin{array}{l}\text { signal transducer and } \\
\text { activator of transcription } \\
1,91 \mathrm{kDa} \text { gene }\end{array}$ & $\begin{array}{l}\text { A transcriptional activator protein activated } \\
\text { in response to cytokines and growth factors }\end{array}$ & +1.28 & -1.27 & $<0.001$ \\
\hline STAT2 & $\begin{array}{l}\text { signal transducer and } \\
\text { activator of transcription } \\
2,113 \mathrm{kDa} \text { gene }\end{array}$ & $\begin{array}{l}\text { A transcriptional activator protein activated } \\
\text { in response to cytokines and growth factors }\end{array}$ & -1.23 & -1.86 & $<0.001$ \\
\hline
\end{tabular}


Table 1 Gene expression fold-changes between M.bovis-infected $(n=8)$ and control $(n=8)$ based on microarray and real time qRT-PCR analyses (Continued)

\begin{tabular}{|c|c|c|c|c|c|}
\hline TLR3 & Toll-like receptor 3 gene & $\begin{array}{l}\text { An intracellular pathogen recognition } \\
\text { receptor (PRR) that largely recognises viral } \\
\text { pathogen-associated molecular patterns } \\
\text { (PAMPs). Mediates the production of } \\
\text { cytokines necessary for the development of } \\
\text { effective immunity }\end{array}$ & -1.55 & -1.63 & 0.001 \\
\hline TLR4 & Toll-like receptor 4 gene & $\begin{array}{l}\text { A cell-surface PRR that recognises PAMPs } \\
\text { expressed by infectious agents. Mediates the } \\
\text { production of cytokines necessary for the } \\
\text { development of effective immunity }\end{array}$ & +2.41 & Not DE & $>0.05$ \\
\hline TREM1 & $\begin{array}{l}\text { Triggering receptor } \\
\text { expressed on myeloid } \\
\text { cells } 1 \text { gene }\end{array}$ & $\begin{array}{l}\text { A receptor expressed on myeloid cells upon } \\
\text { microbial infection. Amplifies neutrophil and } \\
\text { monocyte-mediated inflammatory responses } \\
\text { stimulating release of pro-inflammatory } \\
\text { chemokines and cytokines }\end{array}$ & -1.70 & -2.81 & 0.002 \\
\hline TYK2 & Tyrosine kinase 2 gene & $\begin{array}{l}\text { A member of the tyrosine kinase. A } \\
\text { component of both interferon signalling } \\
\text { pathways }\end{array}$ & Not represented on array & -1.60 & $<0.001$ \\
\hline TYROBP & $\begin{array}{l}\text { TYRO protein tyrosine } \\
\text { kinase binding protein } \\
\text { gene }\end{array}$ & $\begin{array}{l}\text { A transmembrane protein involved in cell } \\
\text { signalling }\end{array}$ & -1.38 & -1.98 & $<0.001$ \\
\hline
\end{tabular}

Gene descriptions taken from GeneCards version 3 [82] and the NCBI Entrez Gene database [83]. For the microarray data, genes with fold-change differences in expression were significant after adjustment for multiple testing using the Benjamini-Hochberg method [31] (adjusted $P \leq 0.05$ ). 'Not DE' indicates a gene was not differentially expressed between the two sample groups.

to the microarray reference gene list. This analysis showed that the top functional category observed for the DE genes used for IPA was the inflammatory response, which contained 241 genes with $P$-values ranging from $1.66 \times 10^{-11}$ to $1.64 \times 10^{-2}$ (Table 2 ). The inflammatory response category was further sub-divided with the affects immune response subcategory containing the most molecules (138 DE genes) [Figure 3]. Further inspection of the individual genes within this subcategory revealed that there was an over-representation of genes displaying reduced relative expression (89 genes) compared to DE genes showing increased relative expression in the BTB animals (49 genes). This observation was in contrast to the other top functional categories where similar numbers of genes showing increased and decreased relative expression were reported.

Canonical molecular pathways associated with $M$. bovis-infection were analysed using IPA. These canonical pathways were ranked according to $P$-value, which represents the significance of the association between a specific pathway and the genes in the input data set. The majority of the top ranking IPA-identified canonical pathways were involved in cell signalling and communication associated with host innate and adaptive immune responses. Natural killer cell signalling and communication between innate and adaptive immune cells were identified as the top ranking canonical pathways. In addition, TREM1 signalling, dendritic cell maturation, JAK-STAT signalling, T cell signalling, IL6 signalling, chemokine signalling and TLR signalling were among the top twenty IPA-identified canonical pathways (Table 3). Based on the well-documented role of TLR signalling in mycobacterial infection [13,38-42], this canonical pathway overlaid with gene expression results is shown in Figure 4.

\section{Discussion}

The implementation of surveillance and management programmes has done much to reduce the incidence and prevalence of BTB over the past number of decades; however, $M$. bovis infection remains an important livestock disease worldwide. This is due, in part, to welldocumented limitations of the currently available diagnostics tests (such as the SICTT and IFN- $\gamma$ tests) leading to a failure to detect all infected animals [43,44].

In recent years, research has shifted from a focus on protein-based diagnostics to functional genomics technologies that interrogate the host transcriptome in response to $M$. bovis infection. In particular, microarray technologies coupled with the rapid development of more sophisticated bovine genome resources has enabled high-resolution analyses of the genes and cellular pathways governing the host response to infection with $M$. bovis [23,25,45-47]. In the present study, we have compared the transcriptomes of PBL from noninfected control animals with actively-infected BTB animals using a high-density genome-wide bovine microarray platform.

Modulation of the host PBL transcriptome in response to $M$. bovis infection was evident from the large number 
Table 2 Gene ontology (GO) categories identified using IPA

\begin{tabular}{|c|c|c|}
\hline Gene ontology category & $P$-value range & Number of genes \\
\hline Inflammatory response & $1.66 \times 10^{-11}-1.64 \times 10^{-2}$ & 241 \\
\hline Cellular development & $8.95 \times 10^{-10}-1.57 \times 10^{-2}$ & 308 \\
\hline Cellular growth and proliferation & $1.65 \times 10^{-9}-1.57 \times 10^{-2}$ & 333 \\
\hline Haematological system development and function & $1.65 \times 10^{-9}-1.64 \times 10^{-2}$ & 279 \\
\hline Haematopoiesis & $2.60 \times 10^{-8}-1.57 \times 10^{-2}$ & 173 \\
\hline Tissue morphology & $1.78 \times 10^{-7}-1.19 \times 10^{-2}$ & 114 \\
\hline Cellular function and maintenance & $5.44 \times 10^{-7}-1.65 \times 10^{-2}$ & 138 \\
\hline Cell death & $9.57 \times 10^{-7}-1.60 \times 10^{-2}$ & 419 \\
\hline Cell-mediated immune response & $1.06 \times 10^{-6}-1.25 \times 10^{-2}$ & 109 \\
\hline Connective tissue disorders & $1.72 \times 10^{-6}-5.94 \times 10^{-3}$ & 234 \\
\hline Immunological disease & $1.72 \times 10^{-6}-1.57 \times 10^{-2}$ & 344 \\
\hline Inflammatory disease & $1.72 \times 10^{-6}-1.28 \times 10^{-2}$ & 364 \\
\hline Skeletal and muscular disorders & $1.72 \times 10^{-6}-1.22 \times 10^{-2}$ & 235 \\
\hline Infectious disease & $1.82 \times 10^{-6}-1.17 \times 10^{-2}$ & 223 \\
\hline Cell-to-cell signalling and interaction & $8.33 \times 10^{-6}-1.64 \times 10^{-2}$ & 210 \\
\hline Dermatological diseases and conditions & $1.04 \times 10^{-5}-1.57 \times 10^{-2}$ & 107 \\
\hline Free radical scavenging & $1.23 \times 10^{-5}-1.23 \times 10^{-5}$ & 14 \\
\hline Molecular transport & $1.23 \times 10^{-5}-7.43 \times 10^{-3}$ & 86 \\
\hline Cell signalling & $2.40 \times 10^{-5}-7.21 \times 10^{-5}$ & 133 \\
\hline Respiratory disease & $2.86 \times 10^{-5}-1.24 \times 10^{-2}$ & 109 \\
\hline Cellular compromise & $3.09 \times 10^{-5}-1.57 \times 10^{-2}$ & 41 \\
\hline Genetic disorder & $3.39 \times 10^{-5}-1.64 \times 10^{-2}$ & 104 \\
\hline Immune cell trafficking & $3.51 \times 10^{-5}-1.64 \times 10^{-2}$ & 163 \\
\hline Humoral immune response & $5.08 \times 10^{-5}-1.19 \times 10^{-2}$ & 78 \\
\hline Organismal injury and abnormalities & $9.51 \times 10^{-5}-1.05 \times 10^{-2}$ & 81 \\
\hline Tissue development & $1.19 \times 10^{-4}-1.05 \times 10^{-2}$ & 108 \\
\hline Haematological disease & $1.78 \times 10^{-4}-1.35 \times 10^{-2}$ & 162 \\
\hline Gastrointestinal disease & $1.88 \times 10^{-4}-5.51 \times 10^{-3}$ & 42 \\
\hline Hepatic system disease & $1.88 \times 10^{-4}-1.64 \times 10^{-2}$ & 89 \\
\hline Lymphoid tissue structure and development & $1.94 \times 10^{-4}-5.94 \times 10^{-3}$ & 5 \\
\hline Antigen presentation & $3.42 \times 10^{-4}-1.64 \times 10^{-2}$ & 83 \\
\hline Cellular movement & $3.58 \times 10^{-4}-1.63 \times 10^{-2}$ & 157 \\
\hline Vitamin and mineral metabolism & $3.59 \times 10^{-4}-7.21 \times 10^{-3}$ & 74 \\
\hline Antimicrobial response & $3.92 \times 10^{-4}-1.28 \times 10^{-2}$ & 32 \\
\hline Hypersensitivity response & $5.86 \times 10^{-4}-8.60 \times 10^{-3}$ & 31 \\
\hline Infection mechanism & $9.89 \times 10^{-4}-1.57 \times 10^{-2}$ & 39 \\
\hline Gene expression & $1.07 \times 10^{-3}-1.57 \times 10^{-2}$ & 254 \\
\hline Hair and skin development and function & $1.23 \times 10^{-3}-1.57 \times 10^{-2}$ & 22 \\
\hline Post-translational modification & $2.27 \times 10^{-3}-9.78 \times 10^{-3}$ & 84 \\
\hline Cancer & $2.51 \times 10^{-3}-1.57 \times 10^{-2}$ & 385 \\
\hline Endocrine system development and function & $2.65 \times 10^{-3}-2.65 \times 10^{-3}$ & 21 \\
\hline Carbohydrate metabolism & $3.77 \times 10^{-3}-3.77 \times 10^{-3}$ & 6 \\
\hline Cell morphology & $3.77 \times 10^{-3}-1.28 \times 10^{-2}$ & 23 \\
\hline Lipid metabolism & $3.77 \times 10^{-3}-7.43 \times 10^{-3}$ & 17 \\
\hline Neurological disease & $3.77 \times 10^{-3}-1.47 \times 10^{-2}$ & 49 \\
\hline Small molecule biochemistry & $3.77 \times 10^{-3}-7.43 \times 10^{-3}$ & 23 \\
\hline Metabolic disease & $3.91 \times 10^{-3}-3.91 \times 10^{-3}$ & 7 \\
\hline
\end{tabular}


Table 2 Gene ontology (GO) categories identified using IPA (Continued)

\begin{tabular}{llc}
\hline Embryonic development & $4.59 \times 10^{-3}-1.57 \times 10^{-2}$ & 21 \\
\hline Nervous system development and function & $4.59 \times 10^{-5}-1.18 \times 10^{-2}$ & 8 \\
\hline Reproductive system disease & $5.84 \times 10^{-3}-7.54 \times 10^{-3}$ & 79 \\
\hline Cell cycle & $5.94 \times 10^{-3}-1.18 \times 10^{-2}$ & 20 \\
\hline Endocrine system disorders & $5.94 \times 10^{-3}-5.94 \times 10^{-3}$ & 3 \\
\hline Opthalmic disease & $5.94 \times 10^{-3}-6.60 \times 10^{-3}$ & 7 \\
\hline RNA post-transcriptional modification & $6.04 \times 10^{-3}-6.04 \times 10^{-3}$ & 13 \\
\hline Cardiovascular system development and function & $6.68 \times 10^{-3}-1.30 \times 10^{-2}$ & 19 \\
\hline Cell assembly and modification & $6.68 \times 10^{-3}-1.28 \times 10^{-2}$ & 14 \\
\hline Organ development & $6.68 \times 10^{-3}-1.19 \times 10^{-2}$ & 6 \\
\hline Renal and urological system development and function & $1.18 \times 10^{-2}-1.30 \times 10^{-2}$ & 11 \\
\hline Reproductive system development and function & $1.18 \times 10^{-2}-1.18 \times 10^{-2}$ & 4 \\
\hline
\end{tabular}

The top ranking GO categories identified by IPA are listed according to $P$-values. $P$-value ranges are based on subcategory $P$-values within each parent term.

of DE genes between the two experimental groups. Statistical analyses of the microarray data identified a total of 2,757 DE genes. Of these, 1,281 (46\%) showed increased expression and 1,476 (54\%) displayed decreased expression in the BTB group compared to the control animals. It is important to note, however, that the differences in cell subpopulations observed between the $M$. bovis-infected and control animals (Figure 1) may have contributed to the gene expression changes detected between the two experimental groups. Also, the haematology analyser results only provided a general description of the PBL cell subsets and do not provide information concerning $\mathrm{T}$ lymphocyte subsets in the infected and control animal groups. In addition, the cell

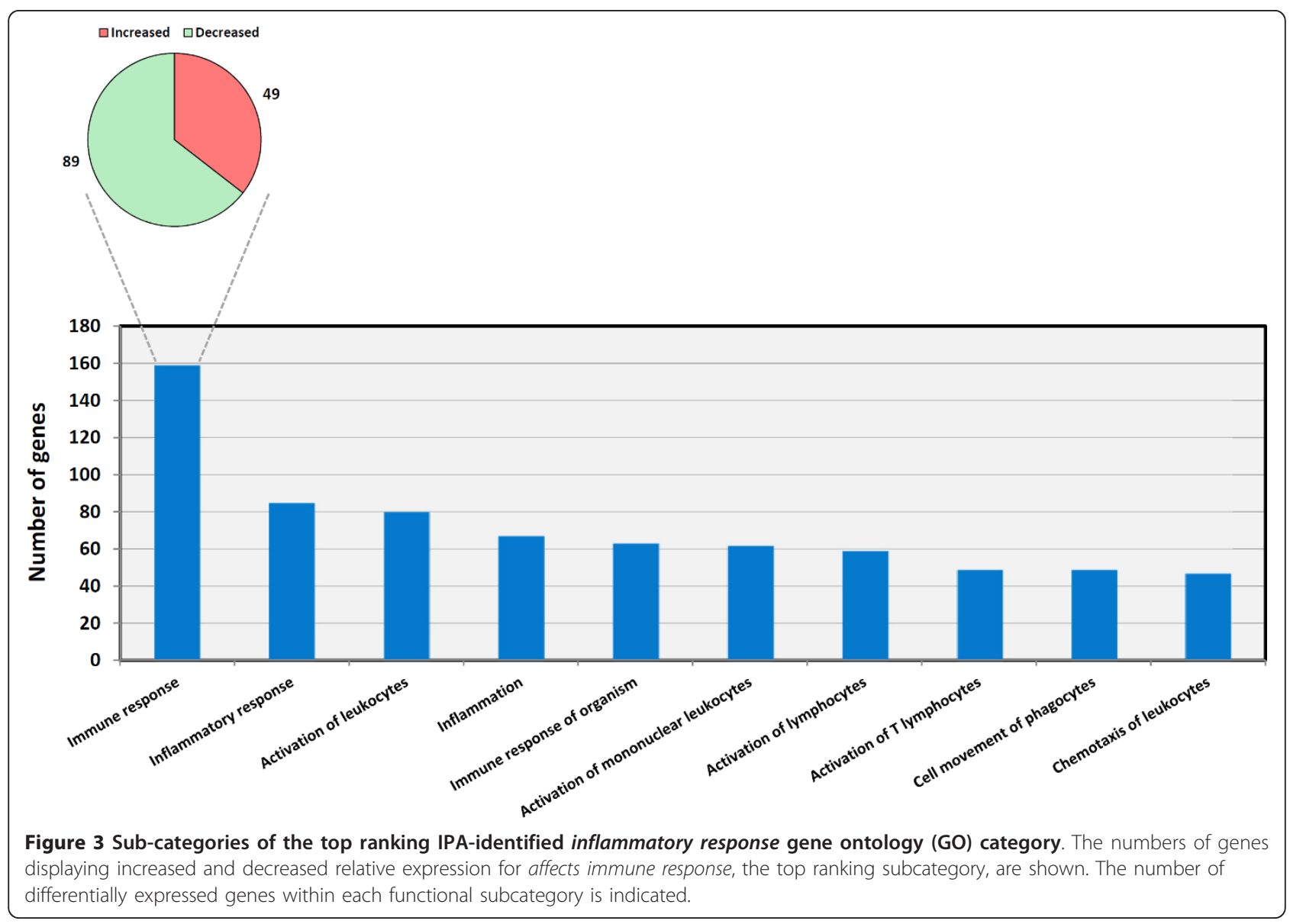


Table 3 Top-ranking canonical pathways identified using IPA

\begin{tabular}{|c|c|c|}
\hline Canonical Pathway Name & $P$-value & Ratio \\
\hline Natural killer cell signalling & $3.06 \times 10^{-4}$ & $23 / 112(0.205)$ \\
\hline Communication between innate and adaptive immune cells & $4.11 \times 10^{-4}$ & $17 / 89(0.191)$ \\
\hline TREM1 signalling & $2.20 \times 10^{-3}$ & $15 / 69(0.217)$ \\
\hline Dendritic cell maturation & $4.96 \times 10^{-3}$ & $29 / 174(0.167)$ \\
\hline Cysteine metabolism & $7.43 \times 10^{-3}$ & 9/90 (0.100) \\
\hline JAK/STAT signalling & $8.22 \times 10^{-3}$ & $15 / 64(0.234)$ \\
\hline NRF2-mediated oxidative stress response & $8.98 \times 10^{-3}$ & $35 / 183(0.191)$ \\
\hline T cell receptor signalling & $1.08 \times 10^{-2}$ & 20/107 (0.187) \\
\hline IL6 signalling & $1.52 \times 10^{-2}$ & 20/93 (0.215) \\
\hline CCR5 signalling in macrophages & $1.84 \times 10^{-2}$ & 16/92 (0.174) \\
\hline Chemokine signalling & $1.92 \times 10^{-2}$ & $15 / 75(0.200)$ \\
\hline Calcium-induced T-lymphocyte apoptosis & $2.07 \times 10^{-2}$ & $12 / 66(0.182)$ \\
\hline IL-17 signalling & $2.21 \times 10^{-2}$ & $16 / 74(0.216)$ \\
\hline Prolactin signalling & $2.21 \times 10^{-2}$ & $16 / 75(0.213)$ \\
\hline Synaptic long term potentiation & $2.22 \times 10^{-2}$ & $19 / 113(0.168)$ \\
\hline Toll-like receptor signalling & $2.63 \times 10^{-2}$ & $11 / 54(0.204)$ \\
\hline FLT3 signalling in hematopoietic progenitor cells & $2.77 \times 10^{-2}$ & $15 / 74(0.203)$ \\
\hline Systemic lupus erythematosus signalling & $2.81 \times 10^{-2}$ & $20 / 151(0.132)$ \\
\hline Renin angiotensin signalling & $3.01 \times 10^{-2}$ & $21 / 120(0.175)$ \\
\hline Phospholipase C signalling & $3.28 \times 10^{-2}$ & $39 / 253(0.154)$ \\
\hline Oncostatin M signalling & $3.36 \times 10^{-2}$ & 9/35 (0.257) \\
\hline Thyroid cancer signalling & $3.36 \times 10^{-2}$ & $9 / 42(0.214)$ \\
\hline B cell receptor signalling & $3.72 \times 10^{-2}$ & $25 / 154(0.162)$ \\
\hline Interferon signalling & $3.97 \times 10^{-2}$ & $6 / 30(0.200)$ \\
\hline Production of nitric oxide and reactive oxygen species in macrophages & $4.13 \times 10^{-2}$ & $28 / 185(0.151)$ \\
\hline NF- $\kappa$ B signalling & $4.17 \times 10^{-2}$ & $25 / 152(0.164)$ \\
\hline Notch signalling & $4.29 \times 10^{-2}$ & $8 / 43(0.186)$ \\
\hline IL10 signalling & $4.36 \times 10^{-2}$ & $13 / 70(0.186)$ \\
\hline P38 MAPK signalling & $4.57 \times 10^{-2}$ & $17 / 97(0.175)$ \\
\hline Role of NFAT in regulation of the immune response & $4.70 \times 10^{-2}$ & $29 / 196(0.148)$ \\
\hline Parkinson's signalling & $5.00 \times 10^{-2}$ & $5 / 17(0.294)$ \\
\hline
\end{tabular}

The top ranking canonical pathways identified by IPA are listed according to $P$-values. The ratio indicates the number of differentially expressed genes involved in each canonical pathway divided by the total number of genes within each pathway as per the IPA Knowledge Base.

subset results presented here differ from previous work performed by us [25], most likely due to the different cell sample types examined.

Analysis of the DE genes using IPA provided information regarding the immunobiology of active $\mathrm{BTB}$. The highest ranking functional category identified using IPA was inflammatory response and the highest ranking subcategory within this category-affects immune responserevealed a marked bias in the number of genes displaying a decrease in relative expression (64.5\%) compared to those showing an increase in relative expression (35.5\%) in PBL from the BTB group.

Previous work by our research group demonstrated that suppression of host gene expression was associated with active $M$. bovis infection in cattle [25]. This earlier work involved the comparison of RNA isolated from PBMC of $M$. bovis-infected and control animals using an immuno-specific bovine cDNA microarray (BOTL-5). The results presented here, based on the analysis of PBL-derived RNA using a genome-wide microarray, lend further support to our previous study. Indeed, published investigations by other workers suggest that transcriptional suppression is a common feature of mycobacterial infection in mammals [48-50].

Further inspection of the inflammatory response functional category in IPA identified several genes that were previously reported to be differentially expressed in cattle and other mammalian species infected with 


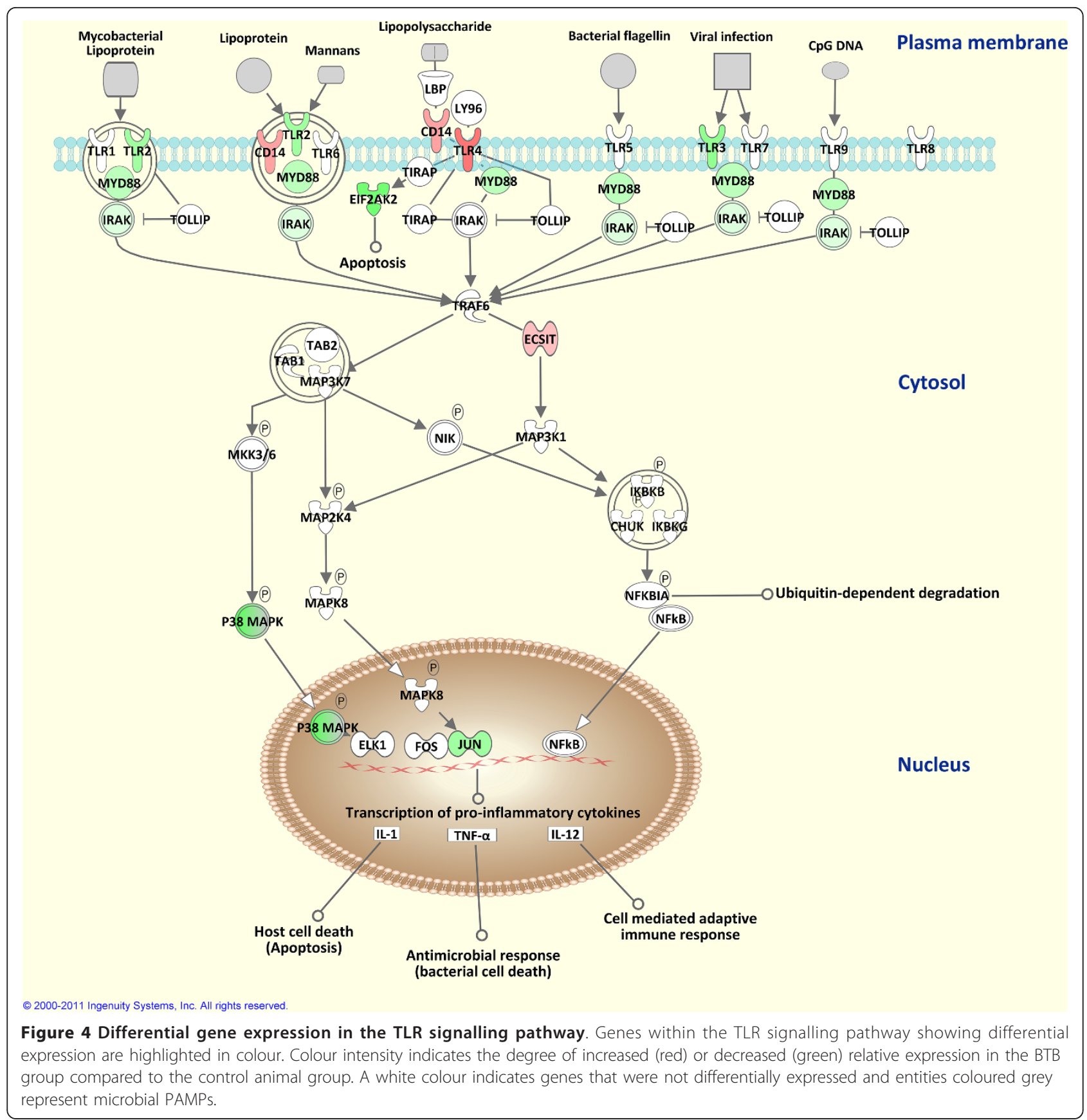

mycobacterial pathogens $[23,40,42,51,52]$. For example, microarray analysis showed that TLR2 and TLR4 displayed contrasting expression patterns between PBL from the two groups: TLR2 showed decreased expression and TLR4 showed increased expression relative to the control animal group. We have previously observed decreased expression of TLR2 in PBMC from actively infected BTB cattle using the immuno-specific BOTL-5 cDNA microarray; however, contrary to the results of the present study, TLR4 also showed decreased expression with the BOTL-5 cDNA microarray in actively infected animals [25].

The gene expression results obtained by Meade and colleagues using PBMC from M. bovis-infected and control non-infected animals were also used to identify a panel of 15 genes predictive of disease status [25]. Four of these genes were found to be similarly differentially expressed in the current study: UNC84B (now SUN2), GAN, SFPQ and NRP1. Four other of the 15 genes identified previously (TBK1, $28 S$ [now RN28S1], GPR98 and 
an anonymous BOTL clone [BOTL0100013_F01]) were not present on the Affymetrix ${ }^{\circledR}$ GeneChip ${ }^{\circledR}$ Bovine Genome Array. However, the seven remaining genes (NCOR1, PPP2R5B, UCP2, ZDHHC19, NFKB1, NRM and $F G F R 1$ ) were not differentially expressed in the PBL samples from $M$. bovis-infected and control non-infected animals used for the present study. This discordance may be due to a number of factors, including: the blood cell sample types used (PBL versus PBMC); differences in sensitivity between the two types of microarray (the single-colour in situ-synthesised Affymetrix ${ }^{\circledR}$ GeneChip ${ }^{\circledR}$ versus a dual-colour spotted cDNA array $[53,54])$; and the requirement for more stringent control of the FDR with larger numbers of genes $(24,072$ probe sets versus 1,391 duplicate spot features).

The role of TLR molecules in the recognition of mycobacterial PAMPs is well established [11,38,39,41,42,55-57]. TLR2 and TLR4 activation signals are linked to the interleukin-1 receptor-associated protein kinases (IRAKs) through the adaptor molecule, myeloid differentiation primary response protein 88 (MYD88), which triggers a downstream protein signalling cascade involving tumour necrosis factor receptorassociated factor 6 (TRAF6) and mitogen-activated protein kinases (MAPKs) $[58,59]$. This cascade culminates in the expression of many NF- $\kappa \mathrm{B}$-inducible genes, including CCL2, IL1B, IL12, IL18 and TNF, causing natural killer (NK) and T cells to release IFN- $\gamma$ and TNF- $\alpha$, which ultimately results in granuloma formation [60].

In the present study, several TLR-mediated proinflammatory cytokines and signalling molecules were differentially expressed in the BTB group compared to the noninfected control animals. These included CCL2 (increased), CXCR4 (increased), CXCL5 (increased), IL1A (increased), IL8 (increased), IL18 (decreased), IRAK4 (decreased), MAPK6 (increased), MAPK13 (decreased), MAPK14 (decreased) and MYD88 (decreased). This was also supported by canonical pathway analysis using IPA, which identified TLR signalling as a molecular pathway affected by $M$. bovis infection.

These results suggest that genes encoding TLRmediated signalling pathway molecules have a role in governing the host response to BTB and may also serve as targets for immuno-subversion by $M$. bovis. For example, genes encoding several innate immune receptors and chemokines (such as TLR4, CD83, CCL2, CXCR4, CXCL5, IL1A and IL8)-several of which participate in the initiation of a $\mathrm{T}$ cell response during infection [61-64] - showed increased relative expression in the BTB animal group. Transcriptional profiles suggesting initiation of a $\mathrm{T}$ cell response are supported by the comparative analysis of the PBL cell populations in the two animal groups; a significant increase in the mean number of lymphocytes and a significant decrease in the mean number of monocytes were observed in the BTB group relative to the control animals. This difference in the PBL cell composition may represent recruitment of host cytotoxic lymphocytes for the destruction of infected monocytes in the control of $M$. bovis infection $[3,65]$.

It is important to note, however, that the observed decreased expression of host PRR genes (such as TLR2) and the genes encoding their associated adaptor and signalling pathway molecules (such as MYD88, IRAK4, MAPK13 and MAPK14) may indicate that the adaptive response in $\mathrm{BTB}$ animals is inferior due to the repression of these innate immune genes. Indeed, previous work has proposed that mycobacterial antigens, such as the early secreted antigenic target protein 6 (ESAT-6) protein, attenuates the host innate immune response by inhibiting MYD88-IRAK4 binding, thus causing suppression of NF- $\kappa \mathrm{B}$-induced transcription of upstream genes required for $\mathrm{T}$ cell response initiation [66]. These workers also demonstrated that activation of v-akt murine thymoma viral oncogene homolog kinases (AKTs) is necessary to prevent MYD88-IRAK4 complex formation. Notably, the AKT2 gene displayed increased relative expression $(+1.22$-fold) in the BTB animal group in the present study.

Repression of host innate immune genes that elicit an adaptive response to $M$. bovis infection is further supported by the analysis of genes belonging to the interferon signalling pathway, which has been shown to have a role in human tuberculosis [37,67-71]. IFN- $\gamma$ is secreted by NK cells and $\mathrm{CD} 4^{+} \mathrm{T}$ cells upon activation by IL- 12 produced by infected macrophages. IFN- $\gamma$ recruits additional macrophages to the site of infection while also providing the stimulus for activating microbicidal functions in infected macrophages [14,71-73]. IFN$\gamma$ also induces MHC class II gene expression in infected macrophages by signalling through its receptor (IFN- $\gamma$ receptor) [74-76]. This stimulates the JAK-STAT pathway, resulting in induction of transcriptional activators of MHC class genes, such as the MHC class II transactivator gene (CIITA). Mycobacterial antigen presentation via MHC class II molecules is critical for the recruitment of additional $\mathrm{CD} 4^{+} \mathrm{T}$ cells and the formation and maintenance of granulomas [38].

The results from the current study support a role for interferon signalling pathways during $M$. bovis infection. The genes encoding interferon (alpha, beta and omega) receptor 2 (IFNAR2); interferon gamma receptor 2 (IFNGR2); interferon-induced protein with tetratricopeptide repeats 2 (IFIT2); interferon-induced protein with tetratricopeptide repeats 5 (IFIT5); interferon-induced transmembrane protein 3 (IFITM3); protein tyrosine phosphatase, non-receptor type 2 (PTPN2); and signal transducer and activator of transcription 2 (STAT2) 
displayed differential expression in the BTB animals based on the microarray and/or real time qRT-PCR analyses.

These findings suggest that, in addition to the targeting of TLR-mediated signalling pathways, $M$. bovis may also target genes involved in the IFN-signalling pathway, resulting in an attenuated $T$ cell response that enables mycobacterial survival and disease progression. It is tempting to speculate that suppression of IFN-signalling in response to $M$. bovis infection may result in the impairment of the antigen presenting process required for adaptive immunity; however, further work is required to investigate this possibility. Notably, the gene encoding IFN- $\gamma$ (IFNG) was not differentially expressed in the current study, despite the BTB animals having tested positive for increased IFN- $\gamma$ based on the Bovi$\mathrm{GAM}^{\circledR}$ assay. However, it is important to note that unlike the blood samples used for the BoviGAM ${ }^{\circledR}$ assay in the current work, the PBL fraction from which the RNA was derived in this study was not stimulated with protein purified derivative of tuberculin (PPD), which is required to elicit IFN- $\gamma$ secretion [4]. In addition, contrary to previous results obtained by Meade and colleagues [25] we did not detect differential expression of the TNF gene between the $M$. bovis-infected and control animals examined here. The most likely explanation for this apparent discrepancy is the different cell sample types used for gene expression analyses (PBL versus PBMC).

IPA canonical pathway analysis identified a number of $\mathrm{DE}$ genes which, to our knowledge, have not previously been reported to be involved in the host response to tuberculosis in cattle or other mammalian species. These included CTLA4 and TLR3. TLR3 encodes an intracellular PRR involved in the recognition of viralderived nucleic acids [77]. In the present study, reduced relative TLR3 expression in BTB animals $(-1.55$-fold) may suggest some hitherto unknown role for this PRR in intracellular mycobacterial infection. In support, we have observed significant differential expression of TLR3 in bovine monocyte-derived macrophages (MDM) stimulated in vitro with $M$. bovis when compared to nonstimulated control MDM (unpublished data). CTLA4 encodes an inhibitor of the $\mathrm{T}$ cell-mediated response $[78,79]$ and this gene displayed increased relative expression (+3.20-fold, $P \leq 0.05)$ in the $M$. bovis infected animals in the present study. The observed increased relative expression of CTLA4 may reflect a mechanism of immuno-modulation used by $M$. bovis to subvert a host $\mathrm{T}$ cell response.

Finally, hierarchical clustering analysis was performed here using a total of 5,388 genes that passed the informative probe filtering criteria. This analysis unambiguously differentiated animals on the basis of their disease status. This result suggests that genome-wide expression profiling of PBL from BTB animals can be used to enable the identification of suitable transcriptional markers for the detection of infected animals within herds and augment current surveillance strategies in countries where control programmes have been implemented $[21,22]$. However, further work using PBL samples from additional animals infected with $M$. bovis and other microbial pathogens will be required to identify and validate robust $M$. bovis-specific transcriptional signatures of infection.

\section{Conclusions}

The results presented here support the hypothesis that repression of immune-related genes is an important feature of mycobacterial infections [25,48-50,80,81]. In particular, the gene expression results obtained suggest that $M$. bovis infection may target the innate immune cellular pathways necessary for the initiation of the appropriate $\mathrm{T}$ cell response. Notably, analysis of the cell populations present in the PBL from the BTB animals showed an increase in the number of lymphocytes relative to the control animals, suggesting that the activelyinfected BTB animals do mount a T cell response. However, it is possible that the $\mathrm{T}$ cell response elicited by these animals is compromised, resulting in disease progression. Indeed, failure of the adaptive immune response to contain the mycobacterial infection is regarded as the primary cause of the development of active tuberculosis from a latent state of infection [74]. Finally, cluster analysis using all informative mRNA transcripts permitted a clear delineation between healthy and infected animals. These results demonstrate that functional genomics approaches based on transcriptional profiling can be used to supplement current proteinbased diagnostics for BTB.

\section{Additional material}

Additional file 1: Perl script used for bootstrapping of cluster analysis results in Figure 2.

Additional file 2: Table S1: Oligonucleotide primers used for real time qRT-PCR validation of microarray results.

\section{Acknowledgements}

This work was supported by Investigator Grants from Science Foundation Ireland (Nos: SFI/01/F.1/B028 and SFI/08/IN.1/B2038), a Research Stimulus Grant from the Department of Agriculture, Fisheries and Food (No: RSF 06 405) and a European Union Framework 7 Project Grant (No: KBBE-211602MACROSYS). KEK is supported by the Irish Research Council for Science, Engineering and Technology (IRCSET) funded Bioinformatics and Systems Biology PhD Programme http://bioinfo-casl.ucd.ie/PhD. We would like to thank Eamonn Costello and staff at the Department of Agriculture, Fisheries and Food, Backweston Laboratory Campus, Celbridge, Co. Kildare for assistance with cattle blood sampling. We also thank Mairéad Doyle and 
Tara Fitzsimons of the UCD Tuberculosis Diagnostics and Immunology Research Centre for performing IFN- $\gamma$ tests.

\section{Author details}

'UCD College of Agriculture, Food Science and Veterinary Medicine, University College Dublin, Belfield, Dublin 4, Ireland. ${ }^{2}$ Animal Bioscience Centre, Teagasc, Grange, Dunsany, County Meath, Ireland. ${ }^{3}$ UCD Conway Institute of Biomolecular and Biomedical Research, University College Dublin, Belfield, Dublin 4, Ireland. ${ }^{4}$ Tuberculosis Diagnostics and Immunology Research Centre, UCD School of Veterinary Medicine, University College Dublin, Belfield, Dublin 4, Ireland. ${ }^{5}$ Comparative Immunology Group, School of Biochemistry and Immunology, Trinity College, Dublin 2, Ireland. 'Smurfit Institute of Genetics, Trinity College Dublin, Dublin 2, Ireland.

\section{Authors' contributions}

KEK was responsible for statistical analyses of microarray data, systems biology analysis and manuscript preparation. JAB was responsible for coordinating microarray preparation, haematological analysis, real time qRTPCR validation of results and manuscript editing. DAM performed statistical analyses and contributed to manuscript preparation and editing. SDEP and $\mathrm{KH}$ contributed to the bioinformatics, statistical analysis and systems biology components of the work. IM performed real time GRT-PCR validation of results. KGM and EG contributed to the experimental design and manuscript editing. SVG and COF contributed to the experimental design, provided valuable comments, discussion and contributed to manuscript preparation and editing. DEM was responsible for the experimental design, coordination of functional genomics data analyses and manuscript preparation and editing. All authors read and approved the final manuscript.

Received: 4 September 2011 Accepted: 19 December 2011

Published: 19 December 2011

\section{References}

1. Waters WR, Palmer MV, Thacker TC, Davis WC, Sreevatsan S, Coussens P, Meade KG, Hope JC, Estes DM: Tuberculosis immunity: opportunities from studies with cattle. Clin Dev Immunol 2011, 2011:768542

2. Skinner MA, Parlane N, McCarthy A, Buddle BM: Cytotoxic T-cell responses to Mycobacterium bovis during experimental infection of cattle with bovine tuberculosis. Immunology 2003, 110(2):234-241.

3. Pollock JM, Neill SD: Mycobacterium bovis infection and tuberculosis in cattle. Vet J 2002, 163(2):115-127

4. Gormley E, Doyle MB, McGill K, Costello E, Good M, Collins JD: The effect of the tuberculin test and the consequences of a delay in blood culture on the sensitivity of a gamma-interferon assay for the detection of Mycobacterium bovis infection in cattle. Vet Immunol Immunopathol 2004, 102(4):413-420.

5. Neill SD, Cassidy J, Hanna J, Mackie DP, Pollock JM, Clements A, Walton E, Bryson DG: Detection of Mycobacterium bovis infection in skin testnegative cattle with an assay for bovine interferon-gamma. Vet Rec 1994, 135(6):134-135.

6. Rothel JS, Jones SL, Corner LA, Cox JC, Wood PR: The gamma-interferon assay for diagnosis of bovine tuberculosis in cattle: conditions affecting the production of gamma-interferon in whole blood culture. Aust Vet $J$ 1992, 69(1):1-4.

7. Alvarez AH, Estrada-Chavez C, Flores-Valdez MA: Molecular findings and approaches spotlighting Mycobacterium bovis persistence in cattle. Vet Res 2009, 40(3):22.

8. Buddle BM, Wedlock DN, Denis M, Vordermeier HM, Hewinson RG: Update on vaccination of cattle and wildlife populations against tuberculosis. Vet Microbiol 2011

9. Netea MG, Ferwerda $G$, de Jong DJ, Jansen $T$, Jacobs L, Kramer M, Naber TH, Drenth JP, Girardin SE, Kullberg BJ, et al: Nucleotide-binding oligomerization domain-2 modulates specific TLR pathways for the induction of cytokine release. J Immunol 2005, 174(10):6518-6523.

10. Ferwerda G, Girardin SE, Kullberg BJ, Le Bourhis L, de Jong DJ, Langenberg DM, van Crevel R, Adema GJ, Ottenhoff TH, Van der Meer JW et al: NOD2 and toll-like receptors are nonredundant recognition systems of Mycobacterium tuberculosis. PLoS Pathog 2005, 1(3):279-285.

11. Means TK, Jones BW, Schromm AB, Shurtleff BA, Smith JA, Keane J, Golenbock DT, Vogel SN, Fenton MJ: Differential effects of a Toll-like receptor antagonist on Mycobacterium tuberculosis-induced macrophage responses. J Immunol 2001, 166(6):4074-4082.

12. Underhill DM, Ozinsky A, Smith KD, Aderem A: Toll-like receptor-2 mediates mycobacteria-induced proinflammatory signaling in macrophages. Proc Natl Acad Sci USA 1999, 96(25):14459-14463.

13. Brightbill HD, Libraty DH, Krutzik SR, Yang RB, Belisle JT, Bleharski JR, Maitland M, Norgard MV, Plevy SE, Smale ST, et al: Host defense mechanisms triggered by microbial lipoproteins through toll-like receptors. Science 1999, 285(5428):732-736.

14. Kleinnijenhuis J, Oosting M, Joosten LA, Netea MG, Van Crevel R: Innate immune recognition of Mycobacterium tuberculosis. Clin Dev Immunol 2011, 2011:405310.

15. Saunders BM, Britton WJ: Life and death in the granuloma: immunopathology of tuberculosis. Immunol Cell Biol 2007, 85(2):103-111.

16. Lin $\mathrm{PL}$, Flynn JL: Understanding latent tuberculosis: a moving target. J Immunol 2010, 185(1):15-22.

17. Parrish NM, Dick JD, Bishai WR: Mechanisms of latency in Mycobacterium tuberculosis. Trends Microbiol 1998, 6(3):107-112

18. Gideon HP, Flynn JL: Latent tuberculosis: what the host "sees"? Immunol Res 2011, 50(2-3):202-212.

19. Pollock JM, Welsh MD, McNair J: Immune responses in bovine tuberculosis: towards new strategies for the diagnosis and control of disease. Vet Immunol Immunopathol 2005, 108(1-2):37-43.

20. Neill SD, Pollock JM, Bryson DB, Hanna J: Pathogenesis of Mycobacterium bovis infection in cattle. Vet Microbiol 1994, 40(1-2):41-52.

21. Zarate-Blades $C R$, Silva $C L$, Passos GA: The impact of transcriptomics on the fight against tuberculosis: focus on biomarkers, BCG vaccination, and immunotherapy. Clin Dev Immunol 2011, 2011:192630.

22. Walzl G, Ronacher K, Hanekom W, Scriba TJ, Zumla A: Immunological biomarkers of tuberculosis. Nat Rev Immunol 2011, 11(5):343-354

23. MacHugh DE, Gormley E, Park SD, Browne JA, Taraktsoglou M, O'Farrelly C, Meade KG: Gene expression profiling of the host response to Mycobacterium bovis infection in cattle. Transbound Emerg Dis 2009, 56(67):204-214.

24. Mistry R, Cliff JM, Clayton CL, Beyers N, Mohamed YS, Wilson PA, Dockrell HM, Wallace DM, van Helden PD, Duncan K, et al: Geneexpression patterns in whole blood identify subjects at risk for recurrent tuberculosis. J Infect Dis 2007, 195(3):357-365.

25. Meade KG, Gormley E, Doyle MB, Fitzsimons T, O'Farrelly C, Costello E, Keane J, Zhao Y, MacHugh DE: Innate gene repression associated with Mycobacterium bovis infection in cattle: toward a gene signature of disease. BMC Genomics 2007, 8:400

26. Costello E, Quigley F, Flynn O, Gogarty A, McGuirk J, Murphy A, Dolan L: Laboratory examination of suspect tuberculous lesions detected on abattoir postmortem examination of cattle from non-reactor herds. Irish Vet J 1998, 51(5):248-250.

27. Gentleman RC, Carey VJ, Bates DM, Bolstad B, Dettling M, Dudoit S, Ellis B, Gautier L, Ge Y, Gentry J, et al: Bioconductor: open software development for computational biology and bioinformatics. Genome Biol 2004, 5(10): R80.

28. Hochreiter S, Clevert DA, Obermayer K: A new summarization method for Affymetrix probe level data. Bioinformatics 2006, 22(8):943-949.

29. van der Laan MJ, Pollard KS: A new algorithm for hybrid hierarchical clustering with visualization and the bootstrap. J Stat Plan Inference 2003, 117(2):275-303.

30. Talloen W, Clevert DA, Hochreiter S, Amaratunga D, Bijnens L, Kass S, Gohlmann HW: I/NI-calls for the exclusion of non-informative genes: a highly effective filtering tool for microarray data. Bioinformatics 2007, 23(21):2897-2902.

31. Benjamini $Y$, Hochberg $Y$ : Controlling the false discovery rate - a practical and powerful approach to multiple testing. J R Stat Soc Series B Stat Methodol 1995, 57(1):289-300

32. Untergasser $A$, Nijveen $H$, Rao $X$, Bisseling $T$, Geurts $R$, Leunissen JA: Primer3Plus, an enhanced web interface to Primer3. Nucleic Acids Res 2007, 35 Web Server: W71-74.

33. Rozen S, Skaletsky H: Primer3 on the WWW for general users and for biologist programmers. Methods Mol Biol 2000, 132:365-386.

34. Hellemans J, Mortier G, De Paepe A, Speleman F, Vandesompele J: qBase relative quantification framework and software for management and automated analysis of real-time quantitative PCR data. Genome Biol 2007, $8(2): R 19$ 
35. Brazma A, Hingamp P, Quackenbush J, Sherlock G, Spellman P, Stoeckert C, Aach J, Ansorge W, Ball CA, Causton HC, et al: Minimum information about a microarray experiment (MIAME)-toward standards for microarray data. Nat Genet 2001, 29(4):365-371

36. Barrett T, Troup DB, Wilhite SE, Ledoux P, Evangelista C, Kim IF, Tomashevsky M, Marshall KA, Phillippy KH, Sherman PM, et al: NCBI GEO: archive for functional genomics data sets - 10 years on. Nucleic Acids Res 2011, , 39 Database: D1005-1010.

37. Berry MP, Graham CM, McNab FW, Xu Z, Bloch SA, Oni T, Wilkinson KA, Banchereau R, Skinner J, Wilkinson RJ, et al: An interferon-inducible neutrophil-driven blood transcriptional signature in human tuberculosis. Nature 2010, 466(7309):973-977.

38. Harding CV, Boom WH: Regulation of antigen presentation by Mycobacterium tuberculosis: a role for Toll-like receptors. Nat Rev Microbiol 2010, 8(4):296-307.

39. Quesniaux V, Fremond C, Jacobs M, Parida S, Nicolle D, Yeremeev V, Bihl F, Erard F, Botha T, Drennan M, et al: Toll-like receptor pathways in the immune responses to mycobacteria. Microbes Infect 2004, 6(10):946-959.

40. Doherty TM, Arditi M: TB, or not TB: that is the question - does TLR signaling hold the answer? J Clin Invest 2004, 114(12):1699-1703.

41. Reiling N, Holscher C, Fehrenbach A, Kroger S, Kirschning CJ, Goyert S, Ehlers S: Cutting edge: Toll-like receptor (TLR)2- and TLR4-mediated pathogen recognition in resistance to airborne infection with Mycobacterium tuberculosis. J Immunol 2002, 169(7):3480-3484.

42. Means TK, Wang SY, Lien E, Yoshimura A, Golenbock DT, Fenton MJ: Human toll-like receptors mediate cellular activation by Mycobacterium tuberculosis. J Immunol 1999, 163(7):3920-3927.

43. Schiller I, Vordermeier HM, Waters WR, Whelan AO, Coad M, Gormley E, Buddle BM, Palmer M, Thacker T, McNair J, et al: Bovine tuberculosis: effect of the tuberculin skin test on in vitro interferon gamma responses. Vet Immunol Immunopathol 2010, 136(1-2):1-11.

44. de la Rua-Domenech R, Goodchild AT, Vordermeier HM, Hewinson RG, Christiansen $\mathrm{KH}$, Clifton-Hadley RS: Ante mortem diagnosis of tuberculosis in cattle: a review of the tuberculin tests, gamma-interferon assay and other ancillary diagnostic techniques. Res Vet Sci 2006, 81(2):190-210.

45. Widdison S, Watson M, Coffey TJ: Early response of bovine alveolar macrophages to infection with live and heat-killed Mycobacterium bovis. Dev Comp Immunol 2011, 35(5):580-591.

46. Reese MG, Moore B, Batchelor C, Salas F, Cunningham F, Marth GT, Stein L, Flicek $P$, Yandell $M$, Eilbeck $K$ : A standard variation file format for human genome sequences. Genome Biol 2010, 11(8):R88.

47. Childers CP, Reese JT, Sundaram JP, Vile DC, Dickens CM, Childs KL, Salih H, Bennett AK, Hagen DE, Adelson DL, et al: Bovine Genome Database: integrated tools for genome annotation and discovery. Nucleic Acids Res 2010, , 39 Database: D830-834.

48. Lesho E, Forestiero FJ, Hirata MH, Hirata RD, Cecon L, Melo FF, Paik SH, Murata Y, Ferguson EW, Wang Z, et al: Transcriptional responses of host peripheral blood cells to tuberculosis infection. Tuberculosis 2011, 91(5):390-399.

49. Galindo RC, Ayoubi P, Naranjo V, Gortazar C, Kocan KM, de la Fuente J: Gene expression profiles of European wild boar naturally infected with Mycobacterium bovis. Vet Immunol Immunopathol 2009, 129(1-2):119-125.

50. Silver RF, Walrath J, Lee H, Jacobson BA, Horton H, Bowman MR, Nocka K, Sypek JP: Human alveolar macrophage gene responses to Mycobacterium tuberculosis strains H37Ra and H37Rv. Am J Respir Cell Mol Biol 2009, 40(4):491-504.

51. Taraktsoglou M, Szalabska U, Magee DA, Browne JA, Sweeney T, Gormley E, MacHugh DE: Transcriptional profiling of immune genes in bovine monocyte-derived macrophages exposed to bacterial antigens. Vet Immunol Immunopathol 2011, 140(1-2):130-139.

52. Saiga $H$, Shimada $Y$, Takeda $K$ : Innate immune effectors in mycobacterial infection. Clin Dev Immunol 2011, 2011:347594.

53. Draghici $S$, Khatri $P$, Eklund AC, Szallasi Z: Reliability and reproducibility issues in DNA microarray measurements. Trends Genet 2006, 22(2):101-109.

54. Woo Y, Affourtit J, Daigle S, Viale A, Johnson K, Naggert J, Churchill G: A comparison of cDNA, oligonucleotide, and Affymetrix GeneChip gene expression microarray platforms. J Biomol Tech 2004, 15(4):276-284.

55. Sweet L, Schorey JS: Glycopeptidolipids from Mycobacterium avium promote macrophage activation in a TLR2- and MyD88-dependent manner. J Leukoc Biol 2006, 80(2):415-423.
56. Heldwein KA, Liang MD, Andresen TK, Thomas KE, Marty AM, Cuesta N, Vogel SN, Fenton MJ: TLR2 and TLR4 serve distinct roles in the host immune response against Mycobacterium bovis BCG. J Leukoc Biol 2003, 74(2):277-286.

57. Means TK, Jones BW, Golenbock DT, Fenton MJ: Toll-like receptor proteins mediate cellular activation by M. tuberculosis bacilli. J Leukoc Biol 2000, 23-23.

58. Kenny EF, O'Neill LAJ: Signalling adaptors used by Toll-like receptors: An update. Cytokine 2008, 43(3):342-349.

59. McGettrick AF, O'Neill LAJ: The expanding family of MyD88-like adaptors in Toll-like receptor signal transduction. Mol Immunol 2004, 41(67):577-582.

60. Korbel DS, Schneider BE, Schaible UE: Innate immunity in tuberculosis: myths and truth. Microbes and Infection 2008, 10(9):995-1004.

61. Flynn JL, Chan J, Lin PL: Macrophages and control of granulomatous inflammation in tuberculosis. Mucosal Immunol 2011, 4(3):271-278.

62. Algood HM, Lin PL, Flynn JL: Tumor necrosis factor and chemokine interactions in the formation and maintenance of granulomas in tuberculosis. Clin Infect Dis 2005, 41(Suppl 3):S189-193.

63. Flynn $\mathrm{J}$ : Immunology of tuberculosis and implications in vaccine development. Tuberculosis 2004, 84(1-2):93-101.

64. Algood HM, Chan J, Flynn JL: Chemokines and tuberculosis. Cytokine Growth Factor Rev 2003, 14(6):467-477.

65. Liebana E, Aranaz A, Aldwell FE, McNair J, Neill SD, Smyth AJ, Pollock JM: Cellular interactions in bovine tuberculosis: release of active mycobacteria from infected macrophages by antigen-stimulated T cells. Immunology 2000, 99(1):23-29.

66. Pathak SK, Basu S, Basu KK, Banerjee A, Pathak S, Bhattacharyya A, Kaisho T, Kundu M, Basu J: Direct extracellular interaction between the early secreted antigen ESAT- 6 of Mycobacterium tuberculosis and TLR2 inhibits TLR signaling in macrophages. Nat Immunol 2007, 8(6):610-618.

67. Kumar P, Agarwal R, Siddiqui I, Vora H, Das G, Sharma P: ESAT6 differentially inhibits IFN-gamma-inducible class II transactivator isoforms in both a TLR2-dependent and -independent manner. Immunol Cell Biol 2011.

68. Herbst S, Schaible UE, Schneider BE: Interferon gamma activated macrophages kill mycobacteria by nitric oxide induced apoptosis. PLOS ONE 2011, 6(5):e19105

69. Fortune SM, Solache A, Jaeger A, Hill PJ, Belisle JT, Bloom BR, Rubin EJ, Ernst JD: Mycobacterium tuberculosis inhibits macrophage responses to IFN-gamma through myeloid differentiation factor 88-dependent and -independent mechanisms. J Immunol 2004, 172(10):6272-6280.

70. Ting LM, Kim AC, Cattamanchi A, Ernst JD: Mycobacterium tuberculosis inhibits IFN-gamma transcriptional responses without inhibiting activation of STAT1. J Immunol 1999, 163(7):3898-3906.

71. Cooper AM, Dalton DK, Stewart TA, Griffin JP, Russell DG, Orme IM: Disseminated tuberculosis in interferon gamma gene-disrupted mice. The Journal of experimental medicine 1993, 178(6):2243-2247.

72. MacMicking JD, Taylor GA, McKinney JD: Immune control of tuberculosis by IFN-gamma-inducible LRG-47. Science 2003, 302(5645):654-659.

73. Flynn JL, Chan J, Triebold KJ, Dalton DK, Stewart TA, Bloom BR: An essential role for interferon gamma in resistance to Mycobacterium tuberculosis infection. J Exp Med 1993, 178(6):2249-2254.

74. Cooper AM: Cell-mediated immune responses in tuberculosis. Annu Rev Immunol 2009, 27:393-422.

75. Bryant $\mathrm{P}$, Ploegh $\mathrm{H}$ : Class II MHC peptide loading by the professionals. Curr Opin Immunol 2004, 16(1):96-102

76. Laupeze B, Fardel O, Onno M, Bertho N, Drenou B, Fauchet R, Amiot L: Differential expression of major histocompatibility complex class la, lb, and II molecules on monocytes-derived dendritic and macrophagic cells. Hum Immunol 1999, 60(7):591-597.

77. Casanova JL, Abel L, Quintana-Murci L: Human TLRs and IL-1Rs in host defense: natural insights from evolutionary, epidemiological, and clinical genetics. Annu Rev Immunol 2011, 29:447-491.

78. Schneider H, Downey J, Smith A, Zinselmeyer BH, Rush C, Brewer JM, Wei B, Hogg N, Garside P, Rudd CE: Reversal of the TCR stop signal by CTLA-4. Science 2006, 313(5795):1972-1975.

79. Gough SC, Walker LS, Sansom DM: CTLA4 gene polymorphism and autoimmunity. Immunol Rev 2005, 204:102-115.

80. Hestvik AL, Hmama Z, Av-Gay Y: Mycobacterial manipulation of the host cell. FEMS Microbiol Rev 2005, 29(5):1041-1050. 
81. Koul A, Herget T, Klebl B, Ullrich A: Interplay between mycobacteria and host signalling pathways. Nat Rev Microbiol 2004, 2(3):189-202.

82. Safran M, Dalah I, Alexander J, Rosen N, Iny Stein T, Shmoish M, Nativ N, Bahir I, Doniger T, Krug H, et al: GeneCards Version 3: the human gene integrator. Database (Oxford) 2010, 2010:baq020.

83. Maglott D, Ostell J, Pruitt KD, Tatusova T: Entrez Gene: gene-centered information at NCBI. Nucleic Acids Res 2011, , 39 Database: D52-57.

doi:10.1186/1471-2164-12-611

Cite this article as: Killick et al:: Genome-wide transcriptional profiling of peripheral blood leukocytes from cattle infected with Mycobacterium bovis reveals suppression of host immune genes. BMC Genomics 2011 12:611.

Submit your next manuscript to BioMed Central and take full advantage of:

- Convenient online submission

- Thorough peer review

- No space constraints or color figure charges

- Immediate publication on acceptance

- Inclusion in PubMed, CAS, Scopus and Google Scholar

- Research which is freely available for redistribution 